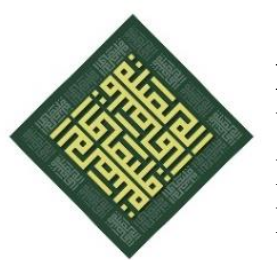

El-Mashlahah

Volume 11 No. 2, December 2021

ISSN: E-ISSN: 2622-8645; P-ISSN: 2089-1970

DOI: $10.23971 /$ elma.v11i2.2958

\title{
THE URGENCY OF PATRIOTISM IN MAINTAINING THE UNITY IN THE REPUBLIC OF INDONESIA IN THE PERSPECTIVE OF MASLAHAH
}

\author{
Zezen Zainul Ali
}

Faculty of Sharia, IAIN Metro Lampung, Indonesia

zezen.uje@gmail.com

Received: 15-06-2021; Accepted:15-12-2021; Published: 23-12-2021;

\begin{abstract}
Patriotism is the willingness of a citizen to protect the country to maintain national unity. Love for the homeland or patriotism often creates pros and cons in its interpretation. Then, it needs to raise awareness as a step to prevent conflicts that arise and consequently cause divisions within the country. The emergence of interpretations between Patriotism and religion that they cannot be combined, so they have willing to change the state ideology to other ideology, such as khiläfah ideology through the emergence of radicalism, extremism, and separatism groups. The research was a literature review using literature data from related books and articles. Data analysis used a qualitative analysis. This study was expected to become a scientific treasure and be practiced in the life of the nation and state. Patriotism explicitly does not available stated in either the Qur'an or Hadith. However, in principle, Islamic law will always answer the problems to provide benefits for mankind, which is the maslahah. Having a love for the homeland is mubah (permitted), but it may switch to be mandatory during emergencies and conditions. This attitude of love for the homeland is in the condition of daruriyah.
\end{abstract}

Keywords: Patriotism; Mașlahah; and Daruriyah;

\section{ABSTRAK}

Patriotisme merupakan kerelaan seseorang warga negara demi menjaga negaranya guna untuk menjaga persatuan bangsa, rasa cinta tanah air atau patriotisme sering kali menimbulkan pro kontra dalam penafsirannya, maka diperlukan pemulihan kesadaran sebagai langkah awal pencegahan konflik yang timbul dan akibatnya menimbulkam perpecahan dalam negara, munculnya penafsiran antara patriotisme dan agama itu tidak dapat menyatu sehingga menginginkan untuk menganti ideologi negara menadi ideologi khiläfah dengan bermuculanya kelompok radikalisme, ektrimisme dan separarstisme. Penelitian ini merupakan pustaka yang dikaji menggunakan data-data literatur yang berasal dari buku dan artikel terkait dan dianalisis secara kualitatif. Kajian ini diharapkan menjadi suatu khasanah keilmuan dan dapat dipraktikkan dalam kehidupan berbangsa dan bernegara. Patriotisme secara eksplisit belum ada baik dalam al-Qur'an maupun hadis. Akan tetapi prinsipnya hukum Islam akan selalu menjawab persoalanpersoalnan yang muncul untuk memberikan kemaslahatan bagi umat manusia yakni mencapai mașlahah. Pada dasarnya memiliki rasa cinta kepada tanah air adalah boleh 
atau mubah akan tetapi hal tersebut bisa menjadi wajib saat situasi dan kondisi yang memang darurat. Sikap cinta tanah air dalam keadaan yang daruriyah.

Kata Kunci: Patriotisme; Mașlaḥah; dan Daruriyah,

\section{Introduction}

A great nation is a nation that upholds patriotism over the spirit of nationality and religion. In Indonesia, this patriotism is a must because it becomes an order and a sense of obedience to the basics of the Indonesian state. Being a person who loves the homeland is proof that someone is religiously kaffah (a whole) because being a follower of religion and being a citizen of a state can do together at the same time. For more than seventy years since Indonesia's independence day, it deserves for every citizen to have high patriotism. An effort to increase love for the homeland is through education which builds the values of patriotism from an early age. This effort is hoped will foster a sense and awareness of patriotism by being loyal to the nation and state. ${ }^{1}$ Although the term patriotism is familiar in the world of education, nowadays in the era of globalization, it is starting to erode because some of the younger generations tend to be more proud of foreign countries. Therefore, it needs to build the values since early and disseminate a sense of patriotism to the younger generation. ${ }^{2}$

Indonesian people, in general, do not understand the true meaning of patriotism. Patriotism is the spirit of love for the homeland. And, widely, patriotism means being willing to sacrifice for the nation and state, humanity, and development. Patriotism can be applied in all aspects of life, starting from family, community, nation, and state.

Patriotism can be manifested either in times of emergency or war and peacetime. Today, patriotism can be implemented by maintaining the unity and brotherhood of the nation and state. Citizens and the younger generation need to improve themselves, try and struggle to fight for the homeland because this is a respectful responsibility in protecting the nation and state. Therefore, the spirit of patriotism needs to be used as a guide in building people's attitudes and behavior.

\footnotetext{
${ }^{1}$ Murdiyah Winarti, "Mengembangkan Nilai Nasionalisme, Patriotisme, Dan Toleransi Melalui Enrichment Dalam Pembelajaran Sejarah Tentang Peranan Yogyakarta Selama Revolusi Kemerdekaan," Historia: Jurnal Pendidik Dan Peneliti Sejarah 1, no. 1 (2017): 13, https://doi.org/10.17509/historia.v1i1.7004.

${ }^{2}$ Novita Pramesela, "Nilai-Nilai Nasionalisme Dan Patriotisme Dalam Buku Pendidikan Agama Dan Budi Pekerti," Journal of Chemical Information and Modeling 53, no. 9 (2017).
} 
Love for the homeland or patriotism often creates pros and cons in its interpretation. Then, it needs to raise awareness as a step to prevent conflicts that arise and consequently cause divisions within the country. ${ }^{3}$ Lately, many groups expressly want to change the Five Pillars or Pancasila Ideology to another ideology. This is a shred of evidence that the groups fail to understand in interpreting patriotism and religion. The group loudly shouted that patriotism is heresy (bid'ah) and infidel (käfir). Pancasila is a tagut. Salute to the flag is haram (forbidden), and so on. The group is dangerous because the goal is to eliminate the love for the homeland which will ultimately change the nation's ideology and destroy the nation. ${ }^{4}$

These groups are often referred to as a group of radical, conservative, and rigid, and willing to establish a khiläfah ideology. They contradict the sense of patriotism and Islam that cannot unite. But, in essence, they can unite into one. This proves the narrowness of thinking and failed interpretations that do not understand patriotic and religious values. Then, how does Islam view this love for the homeland while there is no explicit recommendation to love the homeland? This article examined the urgency of loving to the homeland or patriotism to maintain national unity in the study of mașlahah in Islam for the benefit of the nation and state. And, this study needs to be disseminated to people who are still doubtful about the concept of love for the homeland and misunderstandings about the urgency of patriotism.

There is a lot of research discussing maslahah. For example, the research conducted by Imron Rosyadi, ${ }^{5}$ Agus Hermanto, ${ }^{6}$ and Asmawi. ${ }^{7}$ But, the studies have not studied patriotism yet to maintain the unity of the Republic of Indonesia. Also, research on patriotism, in general, is quite a lot, but the specifics studied from the perspective of

\footnotetext{
${ }^{3}$ Rahmat Wijayanto and J Marzuki, "Penguatan Nilai Patriotik Melalui Pendidikan Bela Negara," JOISH: Jurnal Ilmu Sosial Dan Humaniora 7, no. 2 (2018): 136-46, https://ejournal.undiksha.ac.id/index.php/JISH/article/view/14928.

${ }^{4}$ Hamidulloh Ibda, "Relasi Nilai Nasionalisme Dan Konsep Hubbul Wathan Minal Iman Dalam Pendidikan Islam," International Journal Ihya' 'Ulum Al-Din 19, no. 2 (2017): 245-70, https://doi.org/10.21580/ihya.18.1.1740.

${ }^{5}$ Imron Rosyadi, "Pemikiran Asy-Syatibi Tentang Maslahah Mursalah," Profetika: Jurnal Studi Islam 14, no. 1 (2013): 79-89, https://journals.ums.ac.id/index.php/profetika/article/view/2009.

${ }^{6}$ Agus Hermanto, "Eksistensi Konsep Maslahat Terhadap Paradigma Fikih Feminis Muslim Tentang Hak Dan Kewajiban Suami Istri," Nizham 7, no. 2 (2019): 262-78, https://ejournal.metrouniv.ac.id/index.php/nizham/article/view/1868.

7 Asmawi, “Konseptualisasi Teori Maslahah,” Salam: Jurnal Sosial Dan Budaya Syar'i 1, no. 2 (2014): 311-28, https://doi.org/0.15408/sjsbs.v1i2.1548.
} 
mașlahah have not been carried out. M Alifudin $\operatorname{Ikhsan}^{8}$ tried to examine patriotism from an Islamic perspective which is specified according to the Qur'an and hadith. Therefore, the article has an urgency to find out how maslahah views the patriotism in maintaining the unity of the Republic of Indonesia.

\section{Method}

The article used a literature approach (library review), ${ }^{9}$ which collected faulty data from various sources related to the title. The data was obtained from books and journals as well as related articles. The article focused on solutions and the law of the issues raised. The data collection technique used the documentation method, where this method finds data from various books, journals, articles, and other reliable sources. Data analysis techniques used deductive analysis of general and relevant concepts to conclude the study.

\section{Findings and Discussion}

\section{Patriotism}

Patriotism is a feeling that arises from the bottom of the heart of a citizen to his country to always devote, maintain, protect and defend his homeland from all kinds of threats, both from within and outside, that can damage the unity. Love for the homeland means defending the country or homeland from all kinds of threats. Love for the homeland is reflected in a sense of pride, respect, belonging, and high loyalty to the homeland by its citizens which is reflected in the behavior of defending, protecting, and being willing to sacrifice for the sake of the nation and the country above the personal interests, as well as loving cultural traditions of the nation. The love for the homeland needs to be understood in full meaning and purpose. Love for the homeland is also known as patriotism.

Patriotism is from the word patriot, which means to love the homeland. Patriot means a sense of enthusiasm for the love of the homeland. Patriotism, in wide definition, is the willingness to sacrifice for the nation and state. This patriotism can be applied in every line of life, starting from family, school, community, nation, and

\footnotetext{
${ }^{8}$ M Alifudin Ikhsan, "Nilai-Nilai Cinta Tanah Air Dalam Perspektif Al-Qur'an,” Jurnal Ilmiah Pendidikan Pancasila Dan Kewarganegaraan2 2, no. 2 (2017): 108-14, https://doi.org/http://dx.doi.org/10.17977/um019v2i22017p108.

9 Sabarudin Ahmad, "Hukum Aborsi Akibat Perkosaan (Analisis Hukum Islam Terhadap Peraturan Pemerintah Nomor 61 Tahun 2014 Tentang Kesehatan Reproduksi," El-Mashlahah 8, no. 2 (2018): 162-83, https://doi.org/https://doi.org/10.23971/el-mas.v8i2.1321.
}

https://e-journal.iain-palangkaraya.ac.id/index.php/maslahah/index 
state. ${ }^{10}$ Patriotism is an attitude coming from a sense of love for the homeland, which is the spirit of nationalism. So, it fosters a sense of sacrifice for the nation and country.

Patriotism, according to other sources, patriot means defender of his country. A person who has a patriotic spirit for the sake of his country is willing to sacrifice the soul and body, and property for the pride of the homeland from the invaders or the parties who want to destroy the peace and unity. ${ }^{11}$

Patriotism may define as ethics and moral values. The progress and prosperity of the homeland must be strongly defended even though it needs to sacrifice body and soul. Patriotism is also defined as heroism. The example of patriotism is a defender of the nation and state who has the attitude, behavior, and spirit of loving the homeland and is willing to sacrifice everything for the progress and prosperity of the country. Some attitudes contradict patriotism. First, egoism is selfish and does not care about others. Terrorism is actions of disturbing and creating public panic by spreading terror. Extremism is a strong attitude to struggle the though, by doing whatever it takes to achieve its interests. Separatism is an attitude to separate from a group or nation. Radicalism is an understanding of willing instant change in various ways, including violence.

The feeling of love for the homeland can awaken the soul to be loyal and willing to sacrifice, both body and soul, in carrying out the state's duty to maintain the unity of the state. Then, a sense of will arises to protect, care for and maintain from all types of threats. ${ }^{12}$

\section{Mașlahah as a Sharia Goal}

According to the Indonesian Dictionary, maslahah means anythings that bring good or benefit. ${ }^{13}$ Maslahat is from the Arabic language, namely al-maslahah, which means good / goodness, appropriateness, and usefulness. The opposite of maslahah is mafsadat, which is something that causes damage. ${ }^{14}$

Maslahah may define as anything that brings benefits and reject damage. Generally, maslahah is often used by ushul scholars in establishing a law that is not

\footnotetext{
${ }^{10}$ Happy Francisca, "Patriotisme Dalam Serat Wira Wiyata" (Universitas Negeri Semarang, 2011), http://lib.unnes.ac.id/5318/.

${ }^{11}$ Francisca.

${ }^{12}$ Ikhsan, "Nilai-Nilai Cinta Tanah Air Dalam Perspektif Al-Qur'an."

${ }^{13}$ Rosyadi, "Pemikiran Asy-Syatibi Tentang Maslahah Mursalah."

${ }^{14}$ Asmawi, "Konseptualisasi Teori Maslahah." 
explicitly stated in the texts of the Qur'an and hadith. Maslahah as the goal of the Sharia is divided into three types in establishing law. First, mașlahah mu'tabarah is the benefits that are explicitly stated in the texts of the Qur'an and hadith. Second, mașlahah mulgah is contrary to the texts of the Qur'an and al-Hadith. And, maslahah mursalah is, neither available and nor conflict with the texts of the Qur'an or hadith. ${ }^{15}$

Maslahah is a term that is often discussed in Islamic law. Because maslahat is the goal of Islamic law. Syara' or Sharia is a rule of law revealed by Allah SWT to ensure the benefits of mankind, this goal is called maqāsid al-syariah. ${ }^{16}$ Maqāsid al-syariah defines into two meanings, namely general and specific. In general, maqāsid al-syariah has the definition that Allah and the Messenger of Allah in sending the verses and hadiths can be understood directly with the aim of benefits, while the specific definition, maqāsid al-syariah means realizing benefit from the Qur'an and hadith. ${ }^{17}$

Maqāsid al-syariah has an important role in answering all the new problems that are not explicitly mentioned in the Qur'an and Al-Sunnah. So, maqāsid al-syariah is used as a method in finding and establishing legal certainty on a reason to achieve benefits. ${ }^{18}$ In achieving the benefit, maqāsid al-syariah has priority scales, namely aḍdaruriyyat, al-hajjiyyat, and at-tahsiniyyat. ${ }^{19}$

First, ad-daruriyyat, is the primary goal that must be achieved in human life. If this is not fulfilled, it will have a fatal impact, even, destroy human life, such as in maintaining religion, soul, mind, lineage, and property. ${ }^{20}$

Second, al-hajjiyyat is the secondary goal, which aims to prevent people from things that make life difficult and ease for humans to achieve their interests. This benefit is more on a principle of need, not on the level of necessity. This means, when al-

\footnotetext{
${ }^{15}$ Hermanto, "Eksistensi Konsep Maslahat Terhadap Paradigma Fikih Feminis Muslim Tentang Hak Dan Kewajiban Suami Istri."

16 Fatma Amilia, "Rancangan Undang-Undang Kesetaraan Dan Keadilan Gender (RUU KKG) Dalam Tinjauan Maqashid Asy-Syari'ah," Musawa 11, no. 2 (2012): 213-28, /https://doi.org/10.14421/musawa.2012.112.213-228.

17 Ali Mutakin, "Hubungan Maqashid Al-Syari'ah Dengan Metode Istinbath Hukum," Analisis: Jurnal Studi Keislaman 17, no. 1 (2017), /https://doi.org/10.24042/ajsk.v17i1.1789.

${ }^{18}$ Imam Mustofa, Kajian Fiqh Kontemporer (Yogyakarta: Idea Press, 2017).

19 Yudian Wahyudi, Ushul Fikih Versus Hermeneutika Membaca Islam Dari Kanada Dan Amerika (Yogyakarta: Pesantren Nawesea Press, 2006).

20 Zezen Zainul Ali, "Social Distancing Upaya Pencegahan Penyebaran Covid-19 Perspektif Maqashid Al-Syariah,” Nizham 8, no. 1 (2020): 82-94, https://doi.org/10.32332/nizham.v8i01.2130.
} 
hajjiyyat is not fulfilled, they will not cause damage, but only has a deficiency effect for humans.

Third, at-tahsiniyyat is the tertiary goal, in which this benefit is not required and is not needed but only as a complement of the law. This means, when it is not fulfilled, it will not cause damage and difficulty, but only decrease the beauty as long as not contradict the sharia.

The urgency of the study on maqāsid al-syariah is based on considerations such as Islamic law comes directly from Allah SWT for the benefit of humans, and is always dealing with changes in social reality. Second, Prophet Muhammad SAW, friends, and mujtahid put attention to this study. Third, the results of ijtihad were conducted by mujtahid in understanding maqāsid al-syariah. ${ }^{21}$

In principle, maqāsid al-syariah aim of achieving happiness in life (maslahat), both today and the hereafter. ${ }^{22}$ The rules of fiqh are, taking benefits and avoiding harm, which is the core of the discussion of maqạsid al-syariah because the law must bring benefit.

\section{The Urgency of Patriotism in Maintaining the Unity of the Republic of Indonesia in the Perspective of Mașlahah}

The purpose of law in Islam is for the maslahah (benefits). Maslahah is a product of ijtihad conducted by ulama, which is the purpose of enforcing the law in Islam (maqașid al-syariah). ${ }^{23}$ The article used the method of mașlahah and maqāsid al-syariah in analyzing and examining the issue of patriotism or love for the homeland, which the term is misinterpreted and considers the patriotism is an act of heresy, thogut and so on because it is not explicitly stated in the Qur'an and hadith.

Every matter, in this case, is love for the homeland is permissible, based on the rules of fiqh:

\footnotetext{
${ }^{21}$ Ghofar Shidiq, “Teori Maqashid Al-Syari’ah Dalam Hukum Islam,” Majalah Ilmiah Sultan $\begin{array}{lcc}\text { Agung } & \text { 44, } & 118 \\ \text { http://jurnal.unissula.ac.id/index.php/majalahilmiahsultanagung/article/view/15. }\end{array}$

${ }^{22}$ Mukharom and Havis Aravik, "Kebijakan Nabi Muhammad Saw Menangani Wabah Penyakit Menular Dan Implementasinya Dalam Konteks Penanggulangan Coronavirus Covid-19," Salam: Jurnal Sosial Dan Budaya Syar'i 7, no. 3 (2020), http://journal.uinjkt.ac.id/index.php/salam/article/view/15096.

${ }^{23}$ Agus Hermanto, "Konsep Maslahat Dalam Menyikapi Masalah Kontemporer (Studi Komparatif Al-Tûfi Dan Al-Ghazali)," Al-'Adalah 14, no. 2 (2017): 433-60, https://doi.org/10.24042/adalah.v14i2.2414.
}

https://e-journal.iain-palangkaraya.ac.id/index.php/maslahah/index 
"The original law is permissible"24

$$
\text { الأصل في الأشياء الإباحة }
$$

This means that if no text prohibits and does not cause damages, it is permissible. The article argues that patriotism may apply to achieve the goals of sharia and maintain the unity, as well as the unity of the nation and state, Moreover, it may be stated as mandatory, following the conditions at the time. Reviewing some of the rules of fiqh are, such as:

$$
\text { الأمور بمقاصدها }
$$

"Everything depends on the goal." 25

This rule is understood that everything depends on the intention. If patriotism is intended to maintain the unity of the nation and state, is willing to sacrifice and guard against the threat that can damage the unity, then it may apply. Furthermore, the rules of fiqh:

$$
\text { لاضرورلاضرار }
$$

"It should not make difficult (others) and not be complicated (by others)"26

This rule teaches us not to make others difficult and be complicated by others. In the context of patriotism, we must not damage the unity of a nation because a division will harm people and come into difficulties. So, patriotism must be applied.

"Rejecting the damages priorly over taking benefit."27

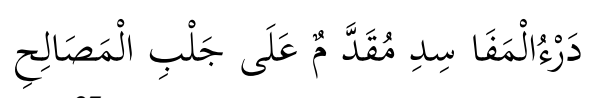

"The harm must be removed." 28

"The harm must be prevented as much as possible." 29

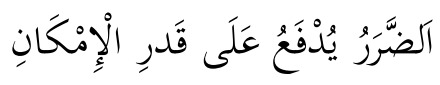

${ }^{24}$ Duski Ibrahim, Al-Qawa'id Al-Fiqhiyah (Kaidah-Kaidah Fiqih) (Yogyakarta: Ar-Ruz Media, 2019).

${ }^{25}$ Ibrahim.

${ }^{26}$ Ibrahim.

${ }^{27}$ Ibrahim.

${ }^{28}$ Hammam Ahmad, "Urgensi Kaidah Fiqhiyyah Dalam Perumusan Hukum Dan Implementasinya Dalam Fatwa DSN-MUI," Et-Tijarie: Jurnal Hukum Dan Bisnis Syariah 4, no. 1 (2017), https://journal.trunojoyo.ac.id/ettijarie/article/view/3900.

${ }^{29}$ Ahmad.

https://e-journal.iain-palangkaraya.ac.id/index.php/maslahah/index 
Some of the previous rules teach us to avoid as much as possible the mufsadat and harm, and put aside benefits first. Because avoiding harm is prioritized over seeking benefits. In this context, patriotism provides a sense of security by maintaining unity and not taking actions that can destroy unity.

Patriotism in an emergency context will automatically become mandatory, the rule, as follows:

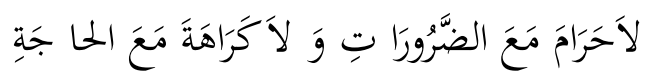

"There is no prohibition for emergency, and no prosperity for necessity"

"Urgent conditions may result in dispensation"

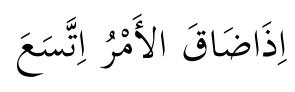

This rule gives an understanding that everything is permissible for the benefits. But, in an emergency, such as defending action from groups who want to destroy the unity of a country, it is a must to fight, even it needs to sacrifice its life to defend the benefits.

Patriotism, discussed through the method of maqāsid al-syariah, can be drawn to a conclusion that the law is mandatory in the daruriyah (emergency) level. And, it is divided into several contexts to maintain the basic principles. They are hifz al-nafs (maintaining the soul) to preserve the soul or life. The love for the homeland is obligatory to be applied because, when citizens in a country do not have a sense of love for the homeland, then it will lead to divisions, or the worse thing is colonization or war. The condition will take many lives. So, the love for the homeland must be built on every citizen to preserve the soul or life.

Hifz al-din is the action of maintaining the religion. If the spirit of love for the homeland disappears, the country will be infiltrated by a deviant ideology using violence by groups who act in the name of religion, but it is actually far from religious values. Here, love for the homeland must be upheld in maintaining and guarding the essence of religion, which is peace.

Patriotism is on the principle in hifz al-nașl (maintaining the lineage) and hifz almâl (maintaining the wealth). It is a condition when the love for the homeland is not found in every citizen so that there is no fortress to maintain the unity of the country. If 
this condition occurs, invaders from other nations may come. After that, there will be chaos, which is the war, freedom of thought will be limited, wealth will not develop, and the fate of the lineage will have no better future. In short, patriotism must be owned by every citizen, in the context of maintaining lineage, wealth, and thought.

\section{Conclusion}

Patriotism as an action in maintaining the unity of the state does not explicitly state in the Qur'an and Hadith. However, in principle, Islamic law will always answer the problems that arise to provide benefits for mankind, namely achieving the goals of sharia (maqāsid al-syariah). Having a love for the homeland or patriotism is mubah or permissible, but becomes mandatory during emergencies and conditions. The attitude of love for the homeland in a daruriyah situation provides legal provisions if threat the five basic principles. They are hifź al-nafs (maintaining the soul), hifź al-din (maintaining religion), hifẓ al-nașl (maintaining keturunan), hifẓ al-māl (maintaining wealth), and hifźal-naql (maintaining thought).

\section{BIBLIOGRAPHY}

Ahmad, Hammam. "Urgensi Kaidah Fiqhiyyah Dalam Perumusan Hukum Dan Implementasinya Dalam Fatwa DSN-MUI." Et-Tijarie: Jurnal Hukum Dan Bisnis Syariah 4, no. 1 (2017). https://journal.trunojoyo.ac.id/ettijarie/article/view/3900.

Ahmad, Sabarudin. "Hukum Aborsi Akibat Perkosaan (Analisis Hukum Islam Terhadap Peraturan Pemerintah Nomor 61 Tahun 2014 Tentang Kesehatan Reproduksi." ElMashlahah 8, no. 2 (2018): 162-83. https://doi.org/https://doi.org/10.23971/elmas.v8i2.1321.

Ali, Zezen Zainul. "Social Distancing Upaya Pencegahan Penyebaran Covid-19 Perspektif Maqashid Al-Syariah.” Nizham 8, no. 1 (2020): 82-94. https://doi.org/10.32332/nizham.v8i01.2130.

Amilia, Fatma. "Rancangan Undang-Undang Kesetaraan Dan Keadilan Gender (RUU KKG) Dalam Tinjauan Maqashid Asy-Syari’ah.” Musawa 11, no. 2 (2012): 21328. https://doi.org/https://doi.org/10.14421/musawa.2012.112.213-228.

Asmawi. “Konseptualisasi Teori Maslahah.” Salam: Jurnal Sosial Dan Budaya Syar'i 1, no. 2 (2014): 311-28. https://doi.org/0.15408/sjsbs.v1i2.1548.

Francisca, Happy. "Patriotisme Dalam Serat Wira Wiyata." Universitas Negeri Semarang, 2011. http://lib.unnes.ac.id/5318/.

Hermanto, Agus. "Eksistensi Konsep Maslahat Terhadap Paradigma Fikih Feminis Muslim Tentang Hak Dan Kewajiban Suami Istri." Nizham 7, no. 2 (2019): 26278. https://e-journal.metrouniv.ac.id/index.php/nizham/article/view/1868.

_. "Konsep Maslahat Dalam Menyikapi Masalah Kontemporer (Studi Komparatif Al-Tûfi Dan Al-Ghazali).” Al-'Adalah 14, no. 2 (2017): 433-60. 
https://doi.org/10.24042/adalah.v14i2.2414.

Ibda, Hamidulloh. "Relasi Nilai Nasionalisme Dan Konsep Hubbul Wathan Minal Iman Dalam Pendidikan Islam." International Journal Ihya' 'Ulum Al-Din 19, no. 2 (2017): 245-70. https://doi.org/10.21580/ihya.18.1.1740.

Ibrahim, Duski. Al-Qawa'id Al-Fiqhiyah (Kaidah-Kaidah Fiqih). Yogyakarta: Ar-Ruz Media, 2019.

Ikhsan, M Alifudin. "Nilai-Nilai Cinta Tanah Air Dalam Perspektif Al-Qur'an.” Jurnal Ilmiah Pendidikan Pancasila Dan Kewarganegaraan2 2, no. 2 (2017): 108-14. https://doi.org/http://dx.doi.org/10.17977/um019v2i22017p108.

Mukharom, and Havis Aravik. "Kebijakan Nabi Muhammad Saw Menangani Wabah Penyakit Menular Dan Implementasinya Dalam Konteks Penanggulangan Coronavirus Covid-19." Salam: Jurnal Sosial Dan Budaya Syar'i 7, no. 3 (2020). http://journal.uinjkt.ac.id/index.php/salam/article/view/15096.

Mustofa, Imam. Kajian Fiqh Kontemporer. Yogyakarta: Idea Press, 2017.

Mutakin, Ali. "Hubungan Maqashid Al-Syari'ah Dengan Metode Istinbath Hukum." Analisis: Jurnal Studi Keislaman 17, no. 1 (2017). https://doi.org/10.24042/ajsk.v17i1.1789.

Pramesela, Novita. "Nilai-Nilai Nasionalisme Dan Patriotisme Dalam Buku Pendidikan Agama Dan Budi Pekerti." Journal of Chemical Information and Modeling 53, no. 9 (2017).

Rosyadi, Imron. "Pemikiran Asy-Syatibi Tentang Maslahah Mursalah." Profetika: Jurnal Studi Islam 14, no. 1 (2013): $79-89$. https://journals.ums.ac.id/index.php/profetika/article/view/2009.

Shidiq, Ghofar. "Teori Maqashid Al-Syari'ah Dalam Hukum Islam.” Majalah Ilmiah $\begin{array}{lllll}\text { Sultan Agung } & \text { 44, no. } & 118 & \text { (2009). }\end{array}$ http://jurnal.unissula.ac.id/index.php/majalahilmiahsultanagung/article/view/15.

Wahyudi, Yudian. Ushul Fikih Versus Hermeneutika Membaca Islam Dari Kanada Dan Amerika. Yogyakarta: Pesantren Nawesea Press, 2006.

Wijayanto, Rahmat, and J Marzuki. "PENGUATAN NILAI PATRIOTIK MELALUI PENDIDIKAN BELA NEGARA.” JOISH: Jurnal Ilmu Sosial Dan Humaniora 7, no. 2 (2018): 136-46. https://ejournal.undiksha.ac.id/index.php/JISH/article/view/14928.

Winarti, Murdiyah. "Mengembangkan Nilai Nasionalisme, Patriotisme, Dan Toleransi Melalui Enrichment Dalam Pembelajaran Sejarah Tentang Peranan Yogyakarta Selama Revolusi Kemerdekaan." Historia: Jurnal Pendidik Dan Peneliti Sejarah 1, no. 1 (2017): 13. https://doi.org/10.17509/historia.v1i1.7004. 